\title{
Analysis of the State and Prospects of Innovative Development of the Russian Economy in Conditions of Its Modernization
}

\author{
Kalenskaya N. V. ${ }^{1} \&$ Pratchenko O. V. ${ }^{2}$ \\ ${ }^{1}$ Kazan Federal University, Institute of Management, Economics and Finance, Kazan, Russia \\ ${ }^{2}$ Kazan Federal University, Institute of Language, Kazan, Russia \\ Correspondence: Kalenskaya N. V., Kazan Federal University, Institute of Management, Economics and Finance, \\ Kazan, 420008, Russia.
}

Received: March 19, 2015 Accepted: March 31, 2015 Online Published: April 30, 2015

doi:10.5539/ass.v11n11p357

URL: http://dx.doi.org/10.5539/ass.v11n11p357

\begin{abstract}
Today, the modernization of the production structure - with the outline of high-tech industries, spheres of science and education as key growth factors - is one of the main conditions of sustainable development of every country, as well as of growth of public prosperity. However, to reach economic stability requires the development of the system research and assessment of innovative economic development, as far as exactly the imperative to study the prospects of innovative development determines modernization of the economy as a whole.

The article presents the analysis of the state of innovative development of the Russian economy and the analysis of key performance indicators of innovative development. It also considers the industrial and regional aspects, and highlights the basic trends of development and the problems of further development.
\end{abstract}

Keywords: innovations, innovative development, modernization, strategy

\section{Introduction}

Transition to the innovative type of development by size, complexity and depth requires fundamental transformation of society in a totally new institutional conditions. Therefore, the grounding methodology of such transition should focus on the long-term perspective, to start from the general principles of planning and forecasting, specifying them in relation to modern conditions, specifics of tasks and nature of the country objectives.

As it is said in "Strategy of development of Russia 2020" ("Conception 2020"), the strategy of innovative development is the only realistic strategy of economic growth. According to the forecasts of the Ministry of Economic Development of the Russian Federation, exactly this strategy should reflect on the macroeconomic results at most (see Table 1), on the economic growth.

Table 1. Strategy of development of Russia 2020 (macroeconomic results)

\begin{tabular}{lcc}
\hline & $\mathbf{2 0 1 0}$ & $\mathbf{2 0 2 0}$ \\
\hline GDP per capita by PPP (thousand dollars) & 13,9 & 30 \\
Average annual rate of growth of GDP, $\%$ & 6,5 \\
Average life expectancy, years & 66,5 & $72-75$ \\
Share of the middle lass, \% & 20 & $>52-55$ \\
Share of population with income below the level of the cost of living, \% $\%$, & 10,4 & $6-6,5$ \\
Share of high-tech sector and the knowledge economy in GDP, \% & 10,9 & $17-20$ \\
Share of innovative products in the industry output, \% & 5,5 & $25-35$ \\
Share of industrial enterprises of innovation, \% $\%, 5$ & $40-50$ \\
Total costs for R\&D, \% GDP & 9,5 \\
Export turnover, billion dollars & 1,1 & $2,5-3$ \\
Export of engineering products, million dollars & 354 & $>900$ \\
Increase in labour productivity, 2020 to 2007 & 19,7 & $110-130$ \\
Dynamics of energy power intencity, \% & 1 & 2,6 \\
DShare of Russia in the world economy, in \% & 100 & 60 \\
\hline
\end{tabular}


Formation of innovative development is impossible without modernization of the economy. Modernization - in the broad sense of the word - is interpreted by researchers as the synthesis of structural, technological and institutional changes in the national economy, aimed at improving its competitiveness in the domestic and international markets; movement from traditions to innovations. Modernization involves:

- mastering of high-tech products manufacturing;

- updating of production facilities and technologies;

- implementation of structural changes in the economy with further increase of the share of products with high added value, including production of high-tech industries, in the GDP;

- professional training, retraining, development of human and intellectual capital;

- involvement into global innovation processes, integration into the world community, the use of achievements of other countries for their own successful development and international cooperation in many economic spheres.

\section{Theory}

The essence of modernization is in concentration of savings and investment in key sectors chosen to be the driving forces of economic development and qualitative transformation of the entire economic system. Thus, modernization is a kind of tool to change the vector of economic development. However, the problem has not been solved yet and it requires urgent measures to change the situation.

Crisis developments in the global and national economy disclosed one of the main failures of the Russian economic development: specific character of structural-reproductive pattern that is characterized by low competitiveness of manufacturing industries and that leads to raw imbalance of the economy and to the corresponding position in the global market. The natural resources availability itself is one of the key factors of development for the country but at the same time the long-term growth rates of countries with significant resources are worse than of countries with similar level of income per capita - but with fewer resources.

Combination of scientific, technical, economic and social aspects of development is necessary for modernization of the Russian economy on the basis of transition to innovative development. Complexity of grounding of policy variants for the long-term period depends on the level of comprehensiveness with which the influence of every direction will be taken into account concerning the others (including the fundamental scientific ideas, mechanism of the economy, social and psychological factors).

Meanwhile, due to the existing economic, industrial and institutional peculiarities of the region, formation of an innovative type of subjects of the Russian Federation is different. It allowed to divide all regions of the Russian Federation into two basic types: the innovation-active and inertial. Figure 1 shows the distribution by regions.

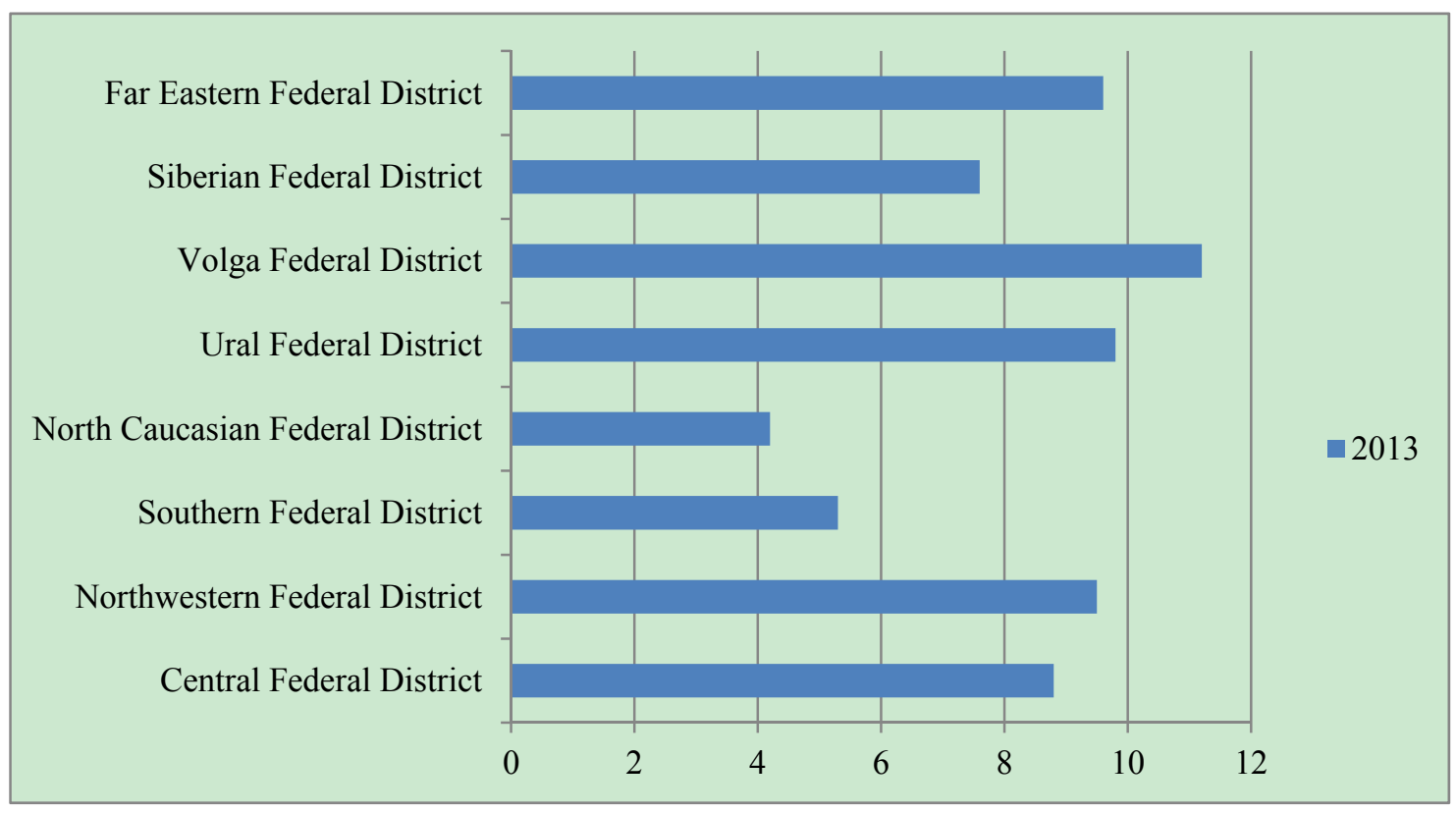

Figure 1. Share of innovatively active enterprises by regions of the Russian Federation in 2013 in \% (2013) 
At this stage of the economic development of Russia, modification of the innovative type - depending on the industry specific nature of the region - is observed. This conclusion is based on the fact that the economic development of the Russian Federation should be considered as the economic development of the set of all its subjects. In our opinion, the study of the process of innovative development in conditions of modernization of the economy on the basis of a synthesis of industry analysis of technological platforms and regional specific nature is of special interest.

General trend of economic modernization comes down to the fact that domination of the innovative development type in industrialized regions (innovatively active) is observed; as a consequence, there is progressive increase of share of organizations implemented technological innovation in Russia. (Figure 2)

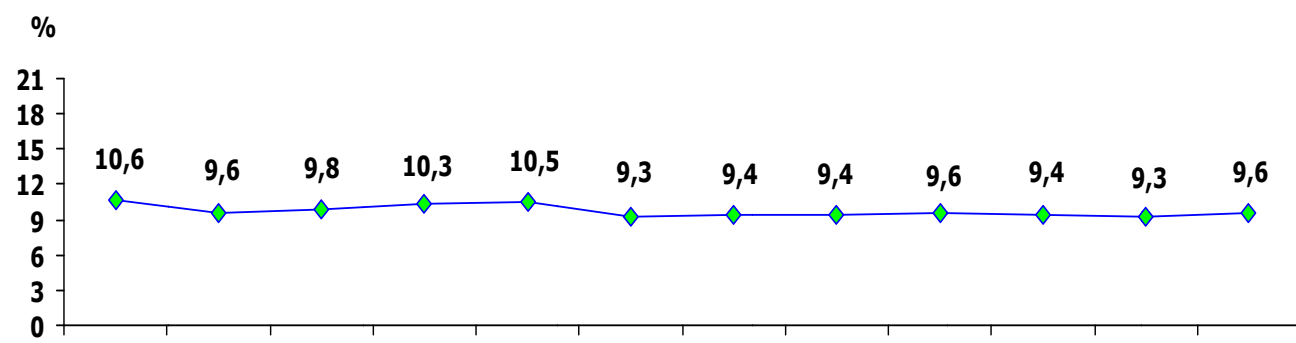

2000 r. 2001 r. 2002 r. 2003 r. 2004 r. 2005 r. 2006 r. 2007 r. 2008 r. 2009 r. 2010 r. 2011 r.

Figure 2. Share of industrial engineering organizations that implement technological innovations, \% (2013)

It is necessary to take into account that technological innovation has industry-specific character (Figure 3), and it proves that within individual sectors of economy the modernization of economy is of "point nature".
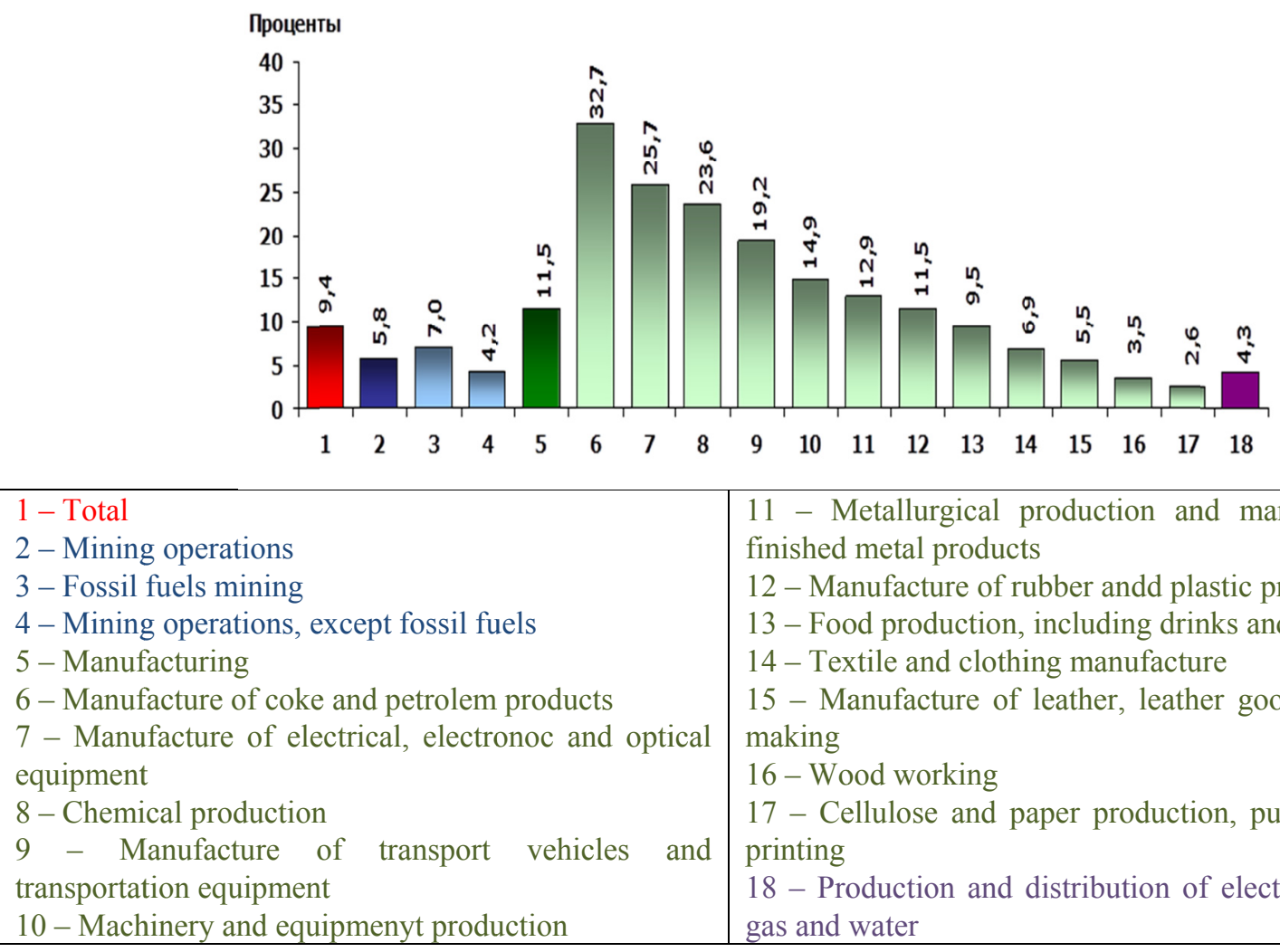

11 - Metallurgical production and manufacture of finished metal products

12 - Manufacture of rubber andd plastic products

13 - Food production, including drinks and tobacco

14 - Textile and clothing manufacture

15 - Manufacture of leather, leather goods and shoe making

16 - Wood working

17 - Cellulose and paper production, publishing and printing

18 - Production and distribution of electrical energy, gas and water

Figure 3. Share of technological innovations by types of economic activity (2013) (2013)

The indicator "Index of innovative activity" is the main assessment indicator of innovative development. The overall index of innovation activity in Russia increased by $18 \%$. (Index is determined by the amount of state support, intensity of legislative work, amount of investments in innovative projects, number of new starts, special events, etc.). (2013). 
In the frames of modernization of economy through innovative development of economic systems, it is necessary to say about the fact that the sphere of energy and energy efficiency is included in the advanced group of industries where there is the growth of innovative projects. Analysis of share of innovative projects by industry is shown on Figure 4.

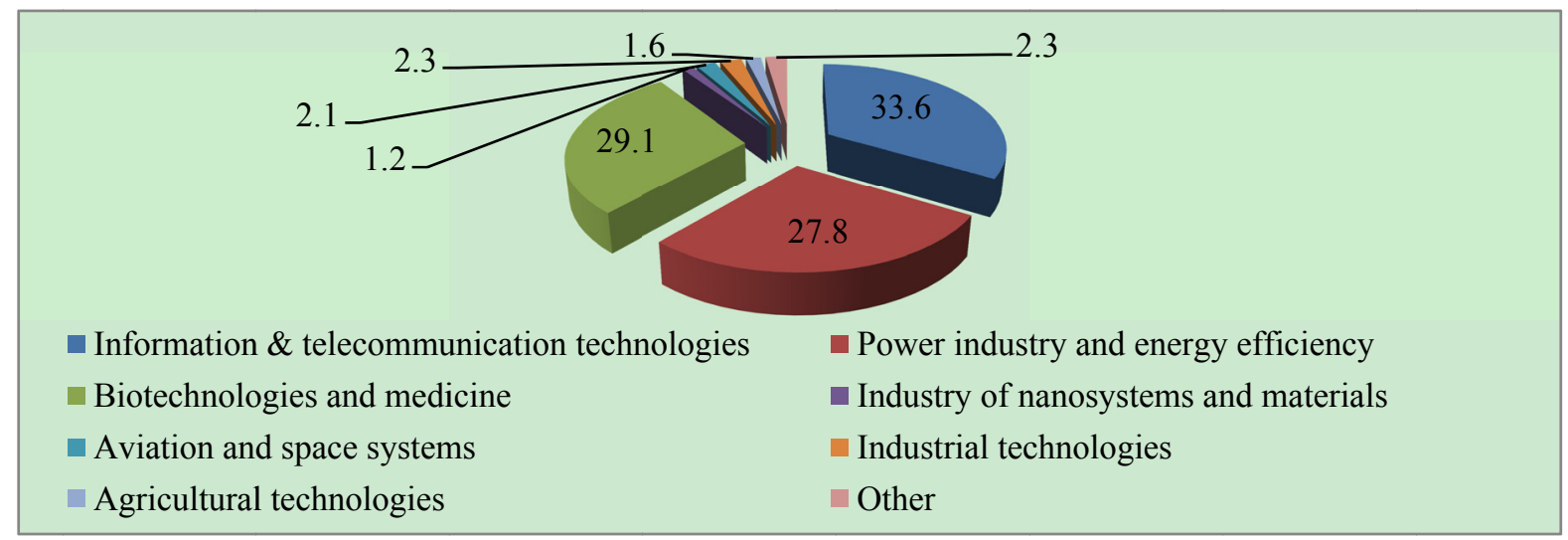

Figure 4. Distribution of innovative products by economic sectors (2013)

As it is seen in Figure 4, the sphere of energy production and energy efficiency refers to the industrial leaders by the quantity of innovative projects $(27,8 \%)$. Moreover, in the structure of the Russian economy the fuel and energy complex (FEC) provides formation of almost $30 \%$ of GDP and accumulates more than $40 \%$ of tax and customs revenues to the budgetary system of the Russian Federation. Today, the fuel and energy complex is characterized by the significant potential in the sphere optimization and efficiency improvement the of operating processes of production, working, transportation and consumption of energy resources by upgrading the technological base that can significantly reduce the amount of investment and operating costs. In general, the noncompliance of the technical level of enterprises of fuel and energy complex to the modern international requirements, as well as the risk of technological inferiority restrict the development of the relevant sectors of the Russian economy.

At the same time, the problem of energy efficiency is important. The effectiveness of energy efficiency is possible at the account of economical energy consumption, as well as thanks to energy-efficient innovative technologies and equipment. Exactly high energy efficiency is considered as a key factor to ensure the competitiveness of some companies and the national economy as a whole and as the basis for innovative development of the Russian economy. However, there is the significant gap between Russia and the developed countries in the sphere of energy efficiency of the national economy. Being on $3^{\text {rd }}$ place by the amount of energy consumption in the world, Russia spends more energy per unit of GDP than any of the countries from the top ten largest energy consumers, thus occupying the $12^{\text {th }}$ place in the list of 121 countries by the energy consumption of the economy. According to a study conducted by the World Bank, in the case of implementation of measures aimed at increase of energy efficiency, every year Russia will be able to save about $45 \%$ of its total consumption of primary energy (2013).

It is also necessary to say that modernization of the Russian economy due to innovative development is the result of the exhaustion of energy resources. Specialists of the Russian Center of Strategic assessment and forecasts analyzed the possible dates of the end of explored reserves of easily accessible oil and gas in the world and in Russia, and in accordance with these estimates the exhaustion of gas will be in 2057 (Sarkisyan \& Gorbatenko, 2009).

According to calculations of the International Energy Agency, 45\% of world electricity should come from alternative sources, and $17 \%$ of them should be based on renewable resources in order to preserve the environmental parameters of the planet by the annual average temperature (http://www.iea.org).

Studies carried out with the support of the World Bank (http://www.iea.org) confirmed that in Russia there is a number of innovative technologies, the application of which would save up to $45 \%$ of energy consumption in the country.

However, innovative development presupposes systemic innovative development in all sectors and spheres of the economy. 
Analyzing the indicators of innovative development of Russia, it is necessary to outline 6 basic positions:

- share of enterprises that implement technological innovations;

- share of Russia in the world markets of hi-technology goods;

- share of export of Russian hi-technology goods;

- gross value added of the innovative sector in GDP;

- share of innovative goods in the total amount of industrial products;

- internal costs for R \& D in GDP.

Comparison of the figures of 2013 is brought down to the forecast predicted values of 2020 (Figure 5).

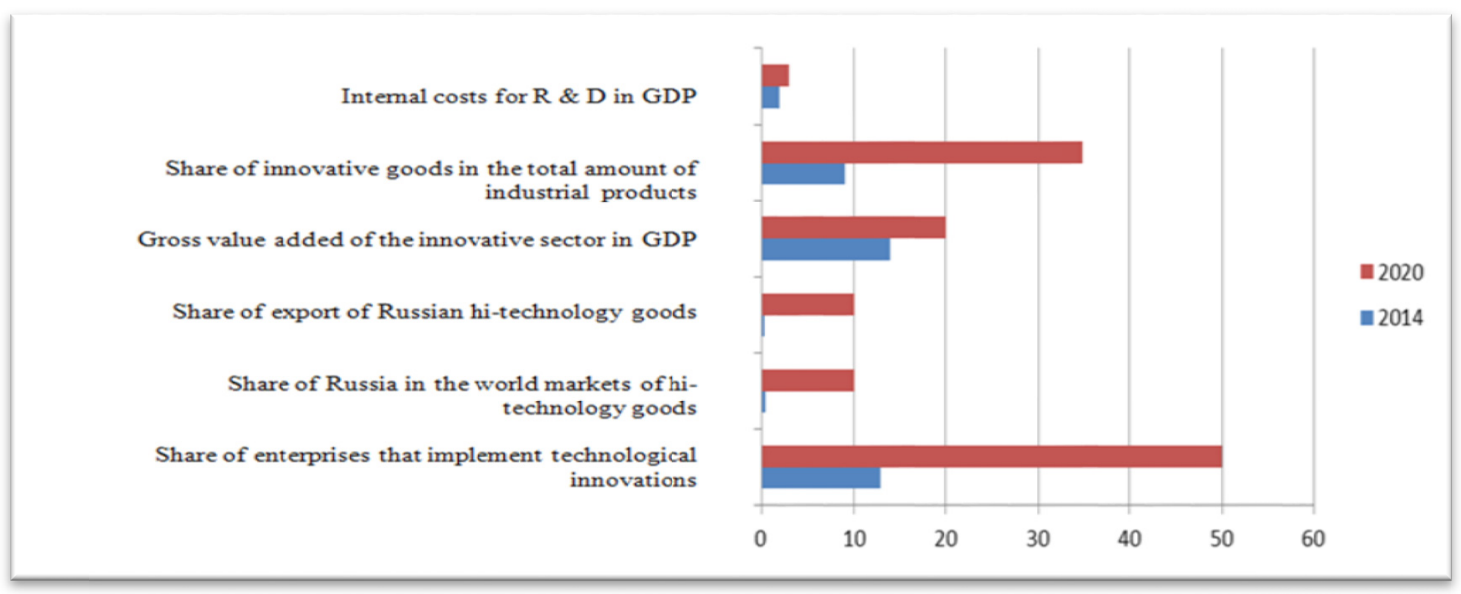

Figure 5. Aggregates of innovative developmet of the Russian Federation

Comparison of current indicators of innovative development to the forecast figures showed that there is a significant lag from the predicted values. According to the series of analytical measures, the problem of financing is in the basis of the little dynamic innovative potential (low innovative growth rates. Statistics of the structure of technological innovations costs is shown on Figure 6, it shows that there is a significant imbalance in the structure of funding sources.

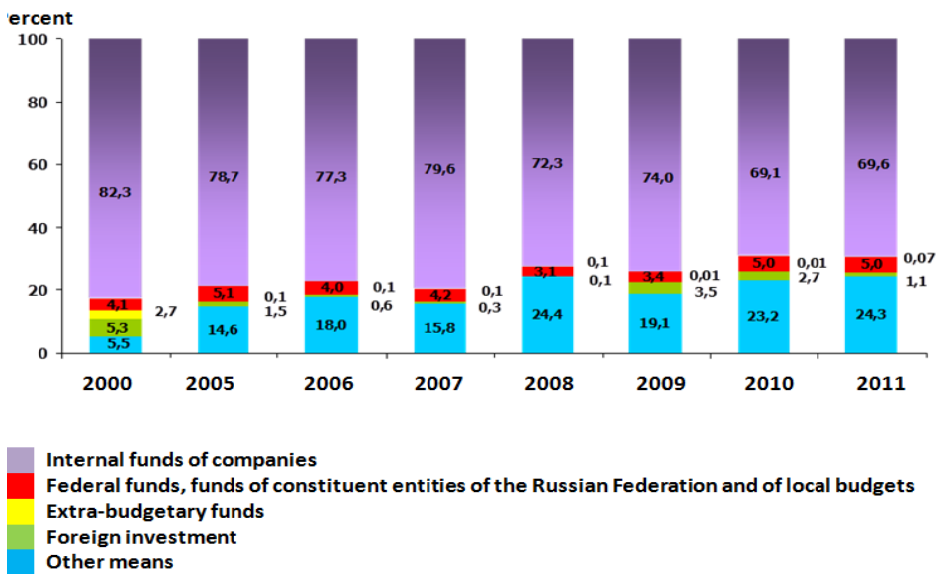

Figure 6. The cost structure for technological innovation by funding source (2013).

\section{Results}

Increasing costs for scientific and technological developments and their implementation in conditions of increasing competition induce many companies to create strategic alliances for implementation of large expensive projects, as well as to move the high-tech industries and centers of scientific-applied research from developed economies to less developed countries. 
According to the analysis of financing sources of innovation, we can conclude that the budget financing carried out on a grant and irrevocable basis is the most profitable type of funding for the organization.

Among the problems of commercialization of development works we can outline the following ones:

- complexity of commercial assessment of the proposed commercial development, technology;

- incompleteness of the majority of research studies;

- the low level of legal literacy;

- incompetency of technology commercialization infrastructure;

- imperfection of market methods of high technology developments commercialization;

- ability to stimulate industrial enterprises, to perceive, to create and to develop scientific and technological achievements.

The fact that on the background of sufficient innovative capacity the majority of Russian companies and enterprises have extremely inefficient mechanism of its use, is a great problem for the Russian innovative sphere.

\section{Conclusion}

Russian industry does not have sufficient resources to pass on innovations, so the innovative sector itself functions very inefficiently. This is due to the fact that the Russian innovation centers are small economic structures, mainly engaged in development of prototypes and implementation of small series production. Therefore, they cannot pass on new products, mainly engaged in the sale (or various forms of transfer) of ideas and technologies.

As for fuel and energy complex, there are also problems within the framework of innovative development:

- not fully realized potential of applied science

- underdevelopment of engineering companies

- difficulties of transfer of advanced foreign technologies

- lack of integrated system of business and science interaction and innovation infrastructure in fuel and energy complex

- increasing deterioration of scientific and engineering personnel training for the high-tech sectors of energy sector, as well as the lack of economic incentives for innovation activities of most enterprises.

Thus, the implementation of a set of measures aimed at introduction of innovative technologies and modern materials in the spheres of fuel and energy sector for the period up to 2018, the support of research and development activities by the priority directions of energy technologies with the following introduction of the results, as well at improvement of the regulatory environment with the use of already existing measures and mechanisms of stimulation of innovative economic development, including financing of related activities, is necessary.

\section{References}

Antonchenko, N. G., \& Kalenskaya, N. V. (2014). Developing a Methodology for Assessing the Efficacy of Managerial Decisions in Entrepreneurial Establishments. Life Science Journal, 11.

Grinyaev, S. N., Fomin, A. N., Kryukova, S. A., \& Makarenko, G. A. (2010). Metodyi prognozirovaniya srokov nastupleniya finansovo-ekonomicheskih krizisov: Analiticheskiy doklad. M.: Tsentr strategicheskih otsenok i prognozov.

Huning, S., Naumann, M., Bens, O., \& Hüttl, R. F. (2011). Transformations of modern infrastructure planning in rural regions: The case of water infrastructures in Brandenburg, Germany. European Planning Studies, 19(8), 1499-1516.

Indikatoryi innovatsionnoy deyatelnosti: 2013: statisticheskiy sbornik. - Moskva: Natsionalnyiy issledovatelskiy universitet «Vyisshaya shkola ekonomiki», 2013. - $472 \mathrm{~s}$.

Kalenskaya, N. V. (2014). The Model of Infrastructural Support of Regional Innovative Development. Mediterranean Journal of Social Sciences, 18, 317-323.

Kalenskaya, N. V., \& Shafigullina, A. V. (2014). The Invariance as a Feature of Business Systems' Infrastructural Innovative Development. Mediterranean Journal of Social Sciences, 18, 241-247.

Kalenskaya, N. V., Akhmetshin, R. M., \& Grigoryeva, L. L. (2014). The Development of State Regulation in 
Small Entrepreneurship Infrastructure Provision. Mediterranean Journal of Social Sciences, 18, 27-33.

Palyakin, R. B., \& Tarkaeva, N. A. (2014). The Relationship of Entrepreneurial Activity and the Level of Institutional and Market-Based Infrastructure of Business. Mediterranean Journal of Social Sciences, 18(5), 305-311.

Rasporyazhenie Pravitelstva Rossiyskoy Federatsii "Vnedrenie innovatsionnyih tehnologiy i sovremennyih materialov v otraslyah toplivno-energeticheskogo kompleksa" ot 3.07.201 \# 1217-r

Rukovodstvo po formirovaniyu energeticheskogo balansa na osnove alternativnyih istochnikov energii. Bryussel, $M E A$. Retrieved from http://novostienergetiki.ru/?p=2369, http://www.iea.org

Sarkisyan, G., \& Gorbatenko, Ya. (2009). Energoeffektivnost v Rossii: skryityiy rezerv. TsENEF

\section{Copyrights}

Copyright for this article is retained by the author(s), with first publication rights granted to the journal.

This is an open-access article distributed under the terms and conditions of the Creative Commons Attribution license (http://creativecommons.org/licenses/by/3.0/ 